\title{
Criminal Enforcement of Copyright as an Important Safeguard for Economic and Security Interests
}

\author{
Ioana Vasiu ${ }^{1}$ and Lucian Vasiu ${ }^{2}$
}

\begin{abstract}
Copyright industries represent an important part of the developed economies. The effective protection of copyright fulfills an important role in the advancement of innovation and economic development. However, in the digital economy, the protection of copyrighted works poses numerous and very difficult challenges. The protected works usually targeted by criminals are computer programs, motion pictures, video games, and musical compositions. The estimated or actual harm to copyright owners can amount to billions of dollars. Moreover, these offenses are sometimes perpetrated in connection with other crimes, such as conspiracy to commit racketeering or money laundering. This paper argues that criminal enforcement of copyright can be an important safeguard of economic and information security interests. The paper discusses essential aspects regarding the criminal protection of copyright in the United States. Based on a theoreticallyinformed, yet empirically-driven approach, which takes into account a large corpus of data, consisting mostly of cases brought to courts of law, the paper discusses the main aspects of the phenomenon. Finally, the paper proposes a number of measures that would improve the protection copyrighted works.
\end{abstract}

Keywords: Copyright, Economic Development, Cybercrime, Infringement, Security, Loss

\section{Introduction}

Creativity industries play an important sustainable development role (UNCTAD, 2016; UNCTAD, 2010; Müller, Rammer \& Trüby, 2009; WIPO, 2003). This statement is supported by a number of recent studies, which show the fundamental role of intellectual property (IP) in the economic activity and the very significant impact of copyright-based industries, both in terms of employment and contribution to the gross domestic product (GDP) (OECD, 2015; WIPO, 2014). In the United States (U.S.), in 2014, the 81 industries identified to be IP-intensive, accounted for about $\$ 6.6$ trillion in value added (38\% of total U.S. GDP), and supported 27.9 million jobs, of which 5.6 million jobs related to copyright-intensive industries (U.S. Patent and Trademark Office, 2016). In the European Union (E.U.), IP-intensive industries account for about $42 \%$ of the GDP and $28 \%$ of direct and $10 \%$ in indirect employment effects (E.U. Intellectual Property Office, 2018).

Copyright industries are a very important part of the IP-intensive industries. The contribution of copyright industries to nations' GDP and employment is the focus of several studies. According to the level of use of copyrighted products, the most important are the "core industries", which comprise film, software, music, performing arts, and television (WIPO, 2014). The "interdependent industries", which include those involved in the production, manufacture, and sale of equipment (for instance, computers), whose role is to facilitate the creation and use of copyrighted works, also

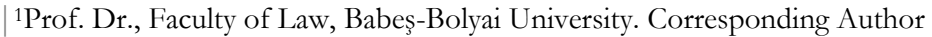

${ }^{2}$ Ph.D., MBA, computer scientist, expert in information systems security systems and cybercrime prevention 
play an important role in the global economy (WIPO, 2014).

Recent figures for specific products provide strong evidence in this sense: in 2016, in the U.S., the software industry, considering the direct, indirect, and induced impacts, had total value-added contribution to the GDP of $\$ 1.14$ trillion and supported 10.5 million jobs (BSA, 2017); in 2017, the global music revenues was well over $\$ 17$ billion (IFPI, 2018); in Europe, retail and rental of physical and digital video surpassed $€ 9$ billion (International Video Federation, 2018).

The level of copyright infringement, however, represents a very significant and growing threat for copyright holders and, in general, economic development (Herz \& Kiljanski, 2018; Butland \& Sullivan, 2018; Matthews, 2017; Hammond, 2014; Adermon \& Liang, 2014). This situation is due to the alarmingly high scope of copyright infringement: the monthly sharing of billions of files, without authorization (Metro-Goldwyn-Mayer Studios Inc. v. Grokster, 2005); around the world, about 100 million Internet Protocol addresses are involved every day in illegal downloading of protected works (Spangler, 2014); in 2017, the U.S. had about 27.9 billion visits to piracy websites (Statista, 2018).

When the rights in protected works are infringed, the owners suffer loss of control and may lose substantial actual or potential advantages, economic or of a different nature. In 2015, for example, the estimated digital infringement level in movies, music, and software was $\$ 213$ billion (Frontier Economics, 2017). The overall economic effects go even further, and negatively affect economic output, jobs, dividends, and tax revenues. The websites dedicated to copyright infringement also raise safety and information security concerns. These sites may expose consumers to criminals, through the surreptitious collection of personally identifying information (PII), which can result in subjecting consumers to fraud, identity theft, or other harms, and can also constitute an infection vector: recent studies underlined the risk of getting infected by malware when installing unlicensed computer programs or when downloading illegally copyrighted works (BSA, 2018; European Union Intellectual Property Office, 2018a; Kumar et al., 2016). Even more concerning, a number of copyright infringement cases involve transborder aspects (U.S. v. Batato, 2016), conspiracy to commit racketeering (U.S. v. All Assets, 2015) or money laundering in connection with these infringement activities (U.S. v. Vaulin, 2017).

The effective protection of copyrighted works supports several goals, including the United Nations' Development Goal 8: “inclusive and sustainable economic growth, employment and decent work for all" (United Nations, 2015) and, in general, the rule of law. Reflecting its importance, various aspects pertaining to copyright's role and protection in the digital economy were discussed in a large number of publications (Okediji, 2018; Danaher, Smith \& Telang, 2017; Bridy, 2016; Morgan, 2016; Poort et al., 2014; Feldman \& Newman, 2013; Harrell, 2013; Mun, 2013; Cohen, 2011; Ross, 2010; Yu, 2010; Lemley \& Reese, 2004; Goldman, 2003).

This paper argues that criminal enforcement of copyright can be an important safeguard of economic and information security interests. In the next section, the paper discusses essential aspects regarding the criminal protection of copyright in the U.S. Next, based on a theoretically-informed, yet empirically-driven approach, which takes into account a large corpus of data, consisting mostly of cases brought to the courts of law, the paper then discusses important perpetration aspects of criminal copyright infringement. Finally, 
the paper proposes a number of measures that could be taken, in order to improve the protection for copyrighted works.

\section{Copyright Framework}

\subsection{Introductory Remarks}

There are four major categories of IP rights: copyright; trademark; patent; and trade secrets. Studies have demonstrated the relations between strong IP protection and increases in direct investments, service imports, and research and development (R\&D) spending (Cavazos Cepeda, Lippoldt \& Senft, 2010). Effective copyright protection is vital nowadays, as technological advances increasingly threaten the creative output, by facilitating the infringing activity and expanding its scope, which can result in lost revenues and the devaluation of the protected products. However, the effective protection of copyright poses numerous and difficult challenges in the digital era.

Copyright is a composite legal concept. Copyright's economic rationale is that the lack of effective enforcement would discourage innovation in new works. Consequently, copyright protection aims to ensure a fair return for creative works: "the ultimate aim is, by this incentive, to stimulate artistic creativity for the general public good" (Twentieth Century Music Corp. v. Aiken, 1975: 156), to "motivate the creative activity of authors and inventors by the provision of a special reward" (Sony Corp. of Am. v. Universal City Studios, 1984: 429).

Copyright protection applies to a variety of products, however, it is limited to "original intellectual conceptions of the author" (Burrow-Giles Lithographic Co. v. Sarony, 1884). Copyright protection "trades off the costs of limiting access to a work against the benefits of providing incentives to create the work in the first place" (Landes \& Posner, 1989:326). The concept of copyright and the related rights, as defined in national legislation, are consistent with the provisions of the Berne Convention for the Protection of Literary and Artistic Works, the WIPO Copyright Treaty, the WIPO Performances and Phonograms Treaty, the Rome Convention, the Agreement on Trade-Related Aspects of Intellectual Property Rights, and other relevant international conventions, and the subject of continuous modernization (for instance, the E.U.'s Copyright Directive and, in the U.S., the Amendments to the Copyright Act as a result of the Orrin G. Hatch-Bob Goodlatte Music Modernization Act of 2018).

\subsection{Copyright Protection}

In the U.S., copyright protection started in 1789, when the Congress discussed "a bill to promote the progress of science and useful arts, by securing to authors and inventors the exclusive right to their respective writings and discoveries" (Eldred v. Ashcroft, 2003). According to 17 U.S.C. \102(a), copyright protection "subsists, in accordance with this title, in original works of authorship fixed in any tangible medium of expression, now known or later developed, from which they can be perceived, reproduced, or otherwise communicated, either directly or with the aid of a machine or device. Works of authorship include the following categories:

(1) literary works;

(2) musical works, including any accompanying words; 
(3) dramatic works, including any accompanying music;

(4) pantomimes and choreographic works;

(5) pictorial, graphic, and sculptural works;

(6) motion pictures and other audiovisual works;

(7) sound recordings; and

(8) architectural works."

As stipulated in 17 U.S.C. \106, copyright owner controls activities such as the reproduction, distribution, creation of derivative works, and public performances or displays of works. According to 17 U.S.C. \ 201(a), the copyright in a work protected, "vests initially in the author or authors of the work", or, when there are more than one author of the work, the authors are co-owners of the copyright.

Copyright protection, as per 17 U.S.C. \ 302, "subsists from its creation and, except as provided by the following subsections, endures for a term consisting of the life of the author and 70 years after the author's death"; for joint works, which have two or more authors, "who did not work for hire, the copyright endures for a term consisting of the life of the last surviving author and 70 years after such last surviving author's death"; in the case of anonymous, pseudonymous, or works made for hire, copyright lasts "for a term of 95 years from the year of its first publication, or a term of 120 years from the year of its creation, whichever expires first".

Copyright protection was initially a civil law matter, and did not contain criminal sanctions. Copyright owners, however, often lack the resources required to combat infringements through civil lawsuits. Criminal copyright protection addresses this situation and proscribes willful infringement of protected works, undertaken either for commercial gain or for some other personal benefit (Haber, 2015).

\subsection{Criminal Infringement of Copyright}

To protect their works, copyright holders, as applicable, can impose contractual obligations and implement technological protection measures (TPMs), such as alphanumeric string or hardware key activation; access control; watermarking; obfuscation; etc. However, the often sophisticated means (for instance, the use of reverse proxy services, employed to diminish the possibility to identify the actual host used in the infringing activity), as well as, in a number of cases, the large-scale scope of infringing activity (e.g., Megaupload, Pirate Bay, or SnappzMarket), in order to be effectively addressed, command strong legal provisions. Additionally, criminal prosecution is also important from a crime deterrence perspective.

Criminal copyright infringement can take several forms, reflected in the legal framework, which includes several offenses:

- copyright infringement for profit (17 U.S.C. \506(a)(1)(A), 18 U.S.C. \2319(b));

- copyright infringement without a profit motive (17 U.S.C. $\int 506(a)(1)(B), 18$

U.S.C. \2319(c));

- pre-release distribution of a copyrighted work over a publicly accessible computer network (17 U.S.C. \506(a)(1)(C), 18 U.S.C. \2319(d));

- circumvention of copyright protection systems (17 U.S.C. \1201);

- trafficking in counterfeit or illicit labels or counterfeit documentation and packaging for copyrighted works (18 U.S.C. \2318); 
- unauthorized fixation of and trafficking in sound recordings and music videos of live musical performances (18 U.S.C. $\int 2319$ A); and

- unauthorized recording of motion pictures in exhibition facilities (18 U.S.C. $\int 2319 B$ ).

This paper focuses on cases of criminal copyright infringement under 17 U.S.C. \ 506. Section 506 proscribes the willful infringement a copyright, where "the infringement was committed-(A) for purposes of commercial advantage or private financial gain; (B) by the reproduction or distribution, including by electronic means, during any 180-day period, of 1 or more copies or phonorecords of 1 or more copyrighted works, which have a total retail value of more than $\$ 1,000$; or $(C)$ by the distribution of a work being prepared for commercial distribution, by making it available on a computer network accessible to members of the public, if such person knew or should have known that the work was intended for commercial distribution".

In general, direct copyright infringement requires plaintiffs to demonstrate ownership of the allegedly infringed product and to prove that the alleged offenders violated at least one exclusive right, granted to copyright holders under 17 U.S.C. \ 106. Civil liability requires the general intent to copy; criminal liability, on the other hand, requires the specific intent to break the law. Therefore, in order to allege a violation of 17 U.S.C. $\int$ 506(a)(1)(A), the prosecution must prove that the infringed works had a valid copyright and that the defendant has (i) willfully (ii) infringed a copyright (iii) for purposes of commercial advantage or private financial gain.

There are a number of remedies in cases of copyright infringement: the offenders are liable for copyright owner's actual damages and any additional profits of the perpetrator or statutory damages (17 U.S.C. \504). 17 U.S.C. \ 503 provides provisions for the impounding and disposition of infringing articles and 18 U.S.C. \ 2323 contains forfeiture, destruction, and restitution provisions. The punishment provisions for criminal copyright infringement are contained in 18 U.S.C. \ 2319 (imprisonment up to 10 years or a fine of up to $\$ 250,000)$.

\section{Characteristics of Criminal Copyright Infringement}

A copyright is infringed "willfully" when the defendant voluntarily and intentionally violated a known legal duty (U.S. v. Moran, 1991). An act is "willful" if "the act is done knowingly and intentionally, not through ignorance, mistake or accident" (U.S. v. Liu, 2013: 988). To prove that defendants acted willfully, the prosecution must demonstrate that they knew their acts infringed a valid copyright or "acted with reckless disregard for, or willful blindness to, plaintiff's rights” (Boffoli v. Atemis, 2019).

Criminal copyright infringement can have both physical and cyberspace components. There are numerous methods through which copyright can be infringed. For example, infringement can take the form of unauthorized reproduction, modification, marketing, distribution, selling, leasing, giving away of protected works, etc. The works that are most often infringed are computer programs, motion pictures, video games, and musical compositions.

Counterfeited CDs and DVDs, containing protected works, such as movies and music, can be encountered widely. The illegal distribution vectors can take numerous forms: selling of counterfeited copies at a flea market (U.S. v. Frison, 2016); warehouse for the 
distribution of counterfeited copies (U.S. Department of Justice, 2013); CDs and DVDs replication plants (U.S. v. Liu, 2013); etc. In U.S. v. Chalupnik (2008), legitimate CDs and DVDs, sold by BMG Columbia, which could not be delivered and should have been discarded, were collected from a post office by the defendant, employed at that facility, then sold at used record stores.

Perpetrators also use "key generators", to create serial numbers, used to activate protected products (U.S. v. Anderson, 2013); purchase and sell illicit or unauthorized product key cards, which contain codes used to gain full access to versions of copyrighted computer programs (U.S. Department of Justice, 2017); or create and disseminate unauthorized copies of re-installation CDs, shipped from other countries (U.S. v. Lundgren, 2018).

Offenders often exploit protected content through the use of a wide array of online technologies. These cases can take numerous forms, such as posting movies on Facebook pages (U.S. Department of Justice, 2017a); selling on eBay.com counterfeited products, shipped from China (U.S. v. Edward, 2013); selling on Amazon.com of illegally copied products (U.S. v. Vampire Nation, 2006).

Digital technologies, such as direct illicit streaming devices (ISDs), download cyberlockers, Internet Protocol Television (IPTV) services, peer-to-peer (P2P) networks and Bit'Torrent portals, are used increasingly, to provide infringing content, usually for monetary gain, often on a massive scale.

In cases of commercial-scale infringement, the harm to copyright holders was very high: $\$ 6.3$ billion in a case that involved the unauthorized downloading of about 1 billion copies of copyrighted works (U.S. Department of Justice, 2018); over \$100 million, in a case of illicit, unauthorized, and counterfeit software products (U.S. Department of Justice, 2015); well in excess of $\$ 500,000,000$, with a reported income exceeding $\$ 175,000,000$, in copyright infringement scheme named "Mega Conspiracy" (U.S. v. Batato, 2016); over \$1 million in the case of "Pirates With Attitudes", which facilitated the unauthorized online dissemination of copyrighted computer programs (U.S. v. Slater, 2003); etc.

In one of the biggest criminal copyright infringement cases, the defendants operated Kickass Torrents (KAT), a website that permitted and promoted the distribution or reproduction of copyrighted content over the Internet, without permission from the copyright owners (U.S. v. Vaulin, 2017). The ill-gotten proceeds in this case came from donations made by website users and from online advertising. To avoid seizures and civil lawsuits, the servers involved in this operation were located and moved around the world. To further conceal their operations, the defendants housed KAT and other related sites under a Ukrainian-based firm.

\section{Conclusion}

Copyrighted works have an important contribution to economic development; consequently, it is mandatory to ensure that they enjoy an adequate level of protection. Copyright protection aims to provide a framework that stimulates individual, organization, and industry level entrepreneurial investments that benefit economic activities. The protection of copyright includes civil and criminal provisions and, where 
applicable, technical measures and contractual obligations for beneficiaries or intermediaries.

This paper, in a concise manner, outlined the main characteristics of the criminal infringement of copyright phenomenon. Criminal copyright infringement is one of the most widespread crimes around the world, negatively affecting innovation and economic opportunities, competition, investments, and revenues. Moreover, the accidental or malicious gathering of PII or the infection of computer systems with various types of contaminants raise serious information security concerns. Even though this paper focused on just one jurisdiction, the findings can be useful to a global context.

Criminal enforcement of copyright can be an effective safeguard for individual, organization, and national economic and security interests. However, for a number of reasons, criminal copyright infringement remains largely under-prosecuted: there is notable "criminal copyright gap between legislation and enforcement" (Haber, 2015: 288). Consequently, there is a clear need to increase the resolve to significantly reduce the criminal infringement of copyrighted works, to ensure consistent and uniform prosecution. This would involve a comprehensive strategy, comprising several dimensions, including: research to analyze the impact of criminal copyright infringement on related industries; improved international law enforcement cooperation, seizure, and forfeiture mechanisms; educational and technical assistance programs; and artificial intelligence (AI) solutions, to effectively detect and address criminal copyright infringement.

\section{References}

Adermon, A., \& Liang, C. Y. (2014). Piracy and Music Sales: The Effects of an Anti-piracy Law. Journal of Economic Behavior \& Organization, 105, 90-106.

Boffoli v. Atemis, No. C18-795 TSZ (W.D. Wash. Feb. 7, 2019).

Bridy, A. (2016). Internet Payment Blockades. Florida Law Review, 67 (5), 1523-1568.

BSA (2017). The Growing $\$ 1$ Trillion Economic Impact of Software.

BSA (2018). Software Management: Security Imperative, Business Opportunity.

Burrow-Giles Lithographic Co. v. Sarony, 111 U. S. 53 (1884).

Butland, N. C. \& Sullivan, J. J. (2018). Pirate Tales from the Deep [Web]: An Exploration of Online Copyright Infringement in the Digital Age. University of Massachusetts Law Review, 13 (1), 50-99.

Cavazos Cepeda, R., Lippoldt, D. \& Senft, J. (2010). Policy Complements to the Strengthening of IPRs in Developing Countries. OECD Trade Policy Working Papers, No. 104, OECD Publishing.

Cohen, J.E. (2011). Copyright as Property in the Post-Industrial Economy: A Research Agenda. Wisconsin Law Review, 2, 141-165.

Danaher, B., Smith, M.D., \& Telang, R. (2017). Copyright Enforcement in the Digital Age: Empirical Evidence and Policy Implications. Communications of the ACM, 60, 68-75.

Eldred v. Ashcroft, 537 U.S. 186, 123 S. Ct. 769, 154 L. Ed. 2d 683 (2003).

European Union Intellectual Property Office (2018). Synthesis Report on IPR Infringement 2018. Retrieved from https://euipo.europa.eu/tunnel-web/secure/webdav/guest/document_library/observatory /docs/Full\%20Report/Full\%20Synthesis\%20Report\%20EN.pdf.

European Union Intellectual Property Office (2018a). Identification and analysis of malware on selected suspected copyright-infringing websites.

Feldman, R. \& Newman, J. (2013). Copyright at the Bedside. Stanford Technology Law Review, 16 (3), 623-655.

Frontier Economics (2017). The Economic Impacts of Counterfeiting and Piracy.

Goldman, E. (2003) A Road to No Warez: The No Electronic Theft Act and Criminal Copyright Infringement. Oregon Law Review, 82, 369-432.

Haber, E. (2015). The Criminal Copyright Gap. Stanford Technology Law Review, 18, 247-288. 
Hammond, R. G. (2014). Profit Leak? Pre-Release File Sharing and the Music Industry. Southern Economic Journal, 81 (2), 387-408.

Harrell, M. J. (2013). Fighting Piracy with Censorship: The Operation in Our Sites Domain Seizures v. Free Speech. Journal of Intellectual Property Law, 21, 137-164.

Herz, B. \& Kiljanski, K. (2018). Movie Piracy and Displaced Sales in Europe: Evidence from Six Countries. Information Economics and Policy, 43, 12-22.

IFPI (2018). Global Music Report 2018.

International Video Federation (2017). European Video Market 2017.

Kumar, S. et al. (2016). Malware in Pirated Software: Case Study of Malware Encounters in Personal Computers. 11th International Conference on Availability, Reliability and Security (ARES), 423-427.

Landes, W.M. \& Posner, R.A. (1989). An Economic Analysis of Copyright Law. The Journal of Legal Studies, $18,325-363$.

Lemley, M.A. \& Reese, R.A. (2004). Reducing Digital Copyright Infringement without Restricting Innovation. Stanford Law Review, 56 (6), 1345-1434.

Matthews, J. (2017). Film Piracy: Surfing the Internet for Free Content Provides Little Bounty for the Collective Economy. Journal of Business, Entrepreneurship \& the Law, 10 (2), 273-297.

Metro-Goldwyn-Mayer Studios Inc. v. Grokster, Ltd., 545 U.S. 913, 125 S. Ct. 2764, 162 L. Ed. $2 d 781$ (2005).

Morgan, S.K. (2016). The International Reach of Criminal Copyright Infringement Laws_Can the Founders of The Pirate Bay Be Held Criminally Responsible in the United States For Copyright Infringement Abroad? Vanderbilt Journal of Transnational Law, 49, 553-595.

Mun, S.-H. (2013). Reality Check: Rethinking the Global Software Piracy Problem. International Telecommunications Policy Review, 20 (2), 1-26.

Müller, K., Rammer, C. \& Trüby, J. (2009). The Role of Creative Industries in Industrial Innovation. Innovation, 11 (2), 148-168.

Okediji, R.L. (2018). Creative Markets and Copyright in the Fourth Industrial Era: Reconfiguring the Public Benefit for a Digital Trade Economy. Geneva: International Centre for Trade and Sustainable Development.

Organisation for Economic Co-operation and Development (OECD) (2015). Copyright in the Digital Era: Country Study. Enquiries into Intellectual Property's Economic Impact.

Poort, J., Leenheer, J., Van der Ham, J., \& Dumitru, C. (2014). Baywatch: Two approaches to measure the effects of blocking access to The Pirate Bay. Telecommunications Policy, 38, 383-392.

Ross, J.L. (2010). A Generation of Racketeers? Eliminating Civil RICO Liability for Copyright Infringement. Vanderbilt Journal of Entertainment and Technology Law, 13, 55-127.

Sony Corp. of Am. v. Universal City Studios, Inc., 464 U.S. 417 (1984).

Spangler, T. (2014). Pirate Bay Shutdown Has Had Virtually No effect on Digital Piracy Levels. Variety. Retrieved from http://variety.com/2014/digital/news/pirate-bay-shutdown-has-had-virtually-noeffect-on-digital-piracy-levels-1201378756/.

Statista (2018). Number of media piracy site visits worldwide 2017. Retrieved from https://www.statista.com/statistics/786046/media-piracy-site-visits-by-country/.

Twentieth Century Music Corp. v. Aiken, 422 U.S. 151, 95 S. Ct. 2040, 45 L. Ed. 2d 84 (1975).

U.S. Department of Justice (2013). Three Indicted for Criminal Copyright Infringement. Retrieved from https://archives.fbi.gov/archives/sacramento/press-releases/2013/three-indicted-for-criminalcopyright-infringement.

U.S. Department of Justice (2015). Six Defendants Plead Guilty to \$100 Million Software Piracy Scheme. Retrieved from https://www.justice.gov/usao-wdmo/pr/six-defendants-plead-guilty-100-millionsoftware-piracy-scheme.

U.S. Department of Justice (2017). Florida Man Pleads Guilty to Software Piracy Scheme. Retrieved from https://www.justice.gov/usao-wdmo/pr/florida-man-pleads-guilty-software-piracy-scheme.

U.S. Department of Justice (2017a). Fresno Man Arrested on Federal Copyright Violations for Alleged Illegal Upload of 'Deadpool' Movie to the Internet. Retrieved from https://www.justice.gov/usao$\mathrm{cdca} / \mathrm{pr} /$ fresno-man-arrested-federal-copyright-violations-alleged-illegal-upload-deadpool-movi-0.

U.S. Department of Justice (2018). Owner of Sharebeast.com sentenced for copyright infringement. Retrieved from https://www.justice.gov/usao-ndga/pr/owner-sharebeastcom-sentencedcopyright-infringement. 
U.S. Patent and Trademark Office (2016). Intellectual Property and the U.S. Economy: 2016 Update.

U.S. v. All Assets Listed in Attachment A, 89 F. Supp. 3d 813 (E.D. Va. 2015).

U.S. v. Anderson, 741 F.3d 938 (9th Cir. 2013).

U.S. v. Batato, 833 F.3d 413 (4th Cir. 2016).

U.S. v. Chalupnik, 514 F.3d 748 (8th Cir. 2008).

U.S. v. Dove, 585 F. Supp. 2d 865 (W.D. Va. 2008).

U.S. v. Edward, No. 12-20705 (E.D. Mich. Dec. 10, 2013).

U.S. v. Frison, 825 F.3d 437 (8th Cir. 2016).

U.S. v. Liu, 731 F.3d 982 (9th Cir. 2013).

U.S. v. Lundgren, No. 17-12466, Non-Argument Calendar (11th Cir. Apr. 11, 2018).

U.S. v. Moran, 757 F.Supp. 1046, 1050-51 (D.Neb.1991).

U.S. v. Slater, 348 F.3d 666 (7th Cir. 2003).

U.S. v. Vampire Nation, 451 F.3d 189 (3d Cir. 2006).

U.S. v. Vaulin, No. 16 CR 438-1 (N.D. Ill. Aug. 4, 2017).

United Nations (2015). Sustainable Development Goals. Retrieved from http://www.un.org/sustainabledevelopment/

United Nations Conference on Trade and Development (UNCTAD) (2016). Creative Economy Statistics, Retrieved from https://unctad.org/en/Pages/DITC/CreativeEconomy/Statistics-on-worldtrade-in-creative-products.aspx

UNCTAD (2010). Creative Economy Report 2010 (UNCTAD/DITC/TAB/2010/3).

World Intellectual Property Organization (WIPO) (2003), Guide on Surveying the Economic Contribution of the Copyright-Based Industries.

WIPO (2014). WIPO Studies on the Economic Contribution of the Copyright Industries.

Yu, P. K. (201). Enforcement, Economics and Estimates. WIPO Journal, 2(1), 1-19. 